\title{
Predictor Role of the Attachment Styles of Mothers on Anxiety Level of Children Starting Primary Schools Preparation
}

\author{
Ayhan Babaroglu \\ Faculty of Health Science, Hitit University, Turkey \\ Received February 8, 2020; Revised March 25, 2020; Accepted March 28, 2020
}

Copyright $@ 2020$ by authors, all rights reserved. Authors agree that this article remains permanently open access under the terms of the Creative Commons Attribution License 4.0 International License

\begin{abstract}
This study aims at examining the predictor role of attachment styles of mothers on the anxiety level of children starting primary school. The study is conducted with 144 mothers who have children who will be starting primary school in the next term. General Information Form, Spence Children's Anxiety Scale (Parent's Form) and Adult Attachment Scale were used to collect data in the study, which is designed with the relational screening model. Kolmogorov-Simirnov test was used to ensure normality assumption in data analysis and it was found that normality assumption of data was fulfilled substantially as a result of the analysis. Thus, parametrical statistical methods were preferred. DUNCAN test was used to determine the groups creating the difference, when there was a difference based on the ANOVA test result. A relationship was found between the mother's attachment styles and sex, income level, and child's reaction to separation from the mother and mother's reaction to separation from the child in the study. However, a relationship could not be found between variables such as the mother's attachment style and number of children, mother's post-partum depression condition, presence of psychosomatic complaints reported by children and whether the child experienced any problems in adjustment to school or not. It was found that secure attachment of the mother was a predictor for the child's panic attack-agoraphobia, fear of physical injury and separation anxiety. Secure attachment of the mother reduces the anxiety in children. The output has shown that the mother transferred the attachment behavior to her children.
\end{abstract}

Keywords Attachment Style, Anxiety, Starting School, Child, Mother

\section{Introduction}

Starting school is a new and exciting process, which is a waited impatiently and which embodies numerous emotions. It is the first time the child is separated from the parents for a long time and faces the external world, in real terms. In fact, most children go through the school adjustment phase without any problems. However, going to school may turn into an endless source of anxiety for some children. Anxiety is actually considered as a normal human emotion and can be defined as perception and interpretation of a potential condition resulting from the internal or external world of the individual as being dangerous. The individual is in an alarmed state when anxious and feels like something is going to happen at all times (Işık, 1996).

Anxiety sources and the reactions of children are different from that of adults. These may emerge with the symptoms of aversion, inaction, not playing games, not wanting to go to school, eating or sleeping orders or in the form of hyperactivity, moodiness, indocibility and behavioral disorders. At times, these may be accompanied by psychosomatic symptoms like headaches, nausea, joint pains etc. (Erdoğan et al., 2002; Kaya et al., 2006; Öztürk, 2007). Prevalence of anxiety disorder varies between $8 \%$ and $27 \%$ in childhood and adolescence (Ollendick \& Hirshfeld-Becker, 2002; Soysal et al., 2005; Tüzün \& Sayar, 2006; Kesebir, Kavzoğlu \& Üstündağ, 2011).

In ethological attachment theory, Bowlby (1973) states that the cause of school anxiety in children may be mainly absence or loss of the persons that they are attached or being away from the environment they feel safe rather than going to school. Results that support this condition reported by Bowlby have been obtained from numerous studies that were conducted (Bernstein et al., 1988; Elliot, 1999; Kearney \& Bates, 2005; Özcan \& Aysev, 2009). Non-fulfillment of the safety requirement and instinct, which is the basic need of the infant leads to anxiety (Shaffer \& Kipp, 2007). Attachment 
theory indicates that different to that of other species, children require close interest of an adult in order to survive (Adler, 2000; Öztürk, 2007). For this purpose, the quality of the relationship of the infant with the mother who is the adult with whom the first and closest relationship is established, does not only improve the chance of survival of the infant but also affects the emotional and social development throughout her/his life (Orta Metin \& Sümer, 2016).

Examination of the studies on starting school and anxiety reveals that these are generally discussed together with the attachment theory (Main et al. 1985; Benoit \& Parker, 1994; George \& Solomon, 1996). Attachment refers to the bond we have with people who are special for us and this bond leads to satisfaction during our interaction with them, feeling of happiness and safety or relief as a result of their closeness when we are anxious or stressful (Berk, 2012). Bowlby (1982) states that attachment is a process that starts with birth and is mainly shaped in the first three years. Although it is not proven conclusively, it is claimed that the first attachment relationship between the mother and the infant is established before birth (Bloom, 1995; Stevens \& Price, 2000). Attachment has two main functions. First of these is the continuation of the affinity to the attachment figure and protection from danger, and secondly, ability to discover the environment independently with the safety provided by the attachment figure (Bowlby, 1982. Any obstacles faced within this system result in anxiety. Anxiety leads to attachment behavior to re-establish the affinity. Attachment behavior is the name given to all kinds of behavior patterns such as crying, smiling, looking, holding etc. that are used to establish and maintain affinity to the attachment figure. Attachment styles of people form a part of the character particulars and exhibit themselves in certain conditions related with attachment such as separation, loss, etc. (Bowlby, 1980).

Attachment is not unique to infants and it also covers childhood, adolescence and adulthood (Ainsworth et al., 1978; Dönmez, 2009)]. There are certain differences between adulthood and childhood attachment styles. First of these differences is that children want to see and have physical contact with the attachment figures, who are seen as safe base, when needed. In adulthood, individuals can feel at ease and safe even if their attachment figures are not with them, based on the knowledge that they can reach their attachment figure whenever they want (Sroufe \&Waters, 1977). Another difference is that attachment relationships of adults are mutual. In other words, the individuals in a relationship are both caregivers and care recipients. In addition, anxiety and stress are among the reasons of affinity-seeking in both childhood and adulthood attachment. Furthermore, seeking protection, relief or sexual affinity may also be an incentive in adulthood attachment (Hazan \& Shaver, 1994).

Although, inheritance of attachment style from generation to generation is still a matter of discussion, Bowlby (1980) claimed that the attachment in early ages is transferred to other generations through internal working models without significant changes. Majority of the studies have shown the existence of similarities between attachment of mothers and attachment of infants (Lippe et al., 2010; Rupert, 2011; Cozolino, 2014). The internal working model that the parents developed with their own parents is transferred to their own children. Thus, the attachment style remains substantially the same and is transferred to following generations. The internal working model is very important because it becomes an inseparable part of personality by serving as a guide for all close relationships in the future (Bowlby, 1973; George \& Soloman, 1999; Zimmermann \& Becker-Stoll, 2002). Van Ijzendoor (1995), who examined the transfer of attachment through generations, presented hard evidence on the fact that the attachment pattern is transferred from the parents to their children. Moreover, it is reported in certain studies that the parent attachment style affects parenthood behavior and that these behaviors have determinant effects on the attachment behaviors of children (Steele \& Stelee, 1994; Van Ijzendoor \& Bakermans-Krannenburg, 1997; Güngör, 2000).

According to the attachment theory, quality of attachment relationships between children and their parents is one of the factors affecting social anxiety. In experiences like starting school, which is considered as a stressful event, children see their attachment figures as a safe base. However, if the mother's attachment style does not entail a secure attachment, this need of the child is not fulfilled, and thus, anxious behaviors may be exhibited. It is found that children who have mothers with insecure attachment also have a greater rate of insecure attachment styles compared to others (Raby et al., 2015). Peleg et al. (2006) found a parallel relationship between separation anxiety in childhood and the separation anxiety of their mothers. Similarly, Manicavasagar et al. (2001) found that $63 \%$ of children with separation anxiety diagnosis had at least one parent with adulthood separation anxiety diagnosis and that separation anxiety was high also in children of parents who are affected, in their study.

Starting primary school is one of the important developmental steps taken in early childhood. This important process may be seen as a potential anxiety source for the child and the mother. Attachment problems extending from the mother may nourish development of anxiety in the child by damaging the mother-child relationship in early childhood. Furthermore, as the mother's attachment behaviors are learnt by the child through observation and imitation, there may be conditioning that has a lifelong effect. Unknowingly, mother will indirectly reflect the reluctance towards separation from the child from her and starting school with implicit messages. If the mother is anxious, the child will exhibit anxious reactions by sensing the situation without requiring any words or explanations. All anxiety problems experienced disrupt the functions of the family and the children seriously. In addition to difficulties experienced by the children, these emerge in the form of difficulties in friendship relations, adaptation to the new environment and academic issues. Considering the notion that anxiety that 
appears in children together with starting school may be related with the attachment styles of the mothers, the attachment styles of the mothers and anxiety condition in children who will be starting school have been examined, and the predictor effect of mother's attachment styles on the anxiety levels of children was investigated along with efforts to collect data on transfer of attachment between generations.

\section{Materials and Methods}

\subsection{Study Model}

This study, which aims at examining the predictor role of mother's attachment styles on the anxiety levels of children starting school, is designed with the relational screening model.

\subsection{Study Group}

144 mothers, who have 72 months old children who will start school in the next education year, constituted the study group. Attention was given to the fact that the mothers are the primary caregivers of the children and voluntarily participating in the research and also being living in the central district of Çorum Province. Mothers were selected from preschool education institutions determined with the random sampling method (Çorum province, which is located at Central Black Sea region of Turkey). Informed consent was obtained from all participants of the study.

It is observed in the examination of the study group that the group consisted of mothers with good level of education (76\% university graduate), who mostly have one or two children (83\%), who are employed (54\% full-time and 29\% part-time), whose marriage is continuing (97\%), who do not have any reported illnesses (94\%) and who consider themselves as having good or average income level (100\%). Furthermore, $29 \%$ of the mothers reported postpartum depression, $46 \%$ reported having problems during separation from their children, and 43\% reported their children experiencing problems during separation from the mother (due to school and other reasons). Regarding school adjustment process of the children, 25\% of mothers reported not having any problems while others stated not having problems in the first 1-2 weeks at a rate of 33\%, first 1-2 months at a rate of $24 \%$ and $5 \%$ at the beginning, after which adjustment problems appeared, and 13\% reported that they are still dealing with adjustment problems.

In addition, 33\% of mothers reported certain psychosomatic complaints (such as stomach-ache, nausea, fever, physical complaints) of their children during school adjustment process. 36\% of mothers described their relationship with their children as being warm and intimate, while $19 \%$ defined it as like a friend, $16 \%$ as challenging and difficult, $14 \%$ as based on rules, and $6 \%$ stated that they are acting in line with the requests of their children. Ethical consent was obtained for the study from the Non-Invasive Ethical Committee of Hittit University (Ref. No: Date 01.03.2018, No: 2018-19).

\subsection{Data Collection}

Consent forms, containing information on the study, were sent to the mothers through the preschool education institutions. Subsequently, the researcher held meetings with each work group and informed the mothers who were interested and obtained signed consent forms from them. In addition to the Information Form, prepared by the researcher, Spence Children's Anxiety Scale - Parent Form and Adult Attachment Style Scale (AASS) were given to the mothers. Mothers filled the forms independently in a quiet environment.

\subsection{Data Collection Tools}

The Information Form, prepared by the researcher, Spence Children's Anxiety Scale - Parent Form and Adult Attachment Style Scale (AASS) were used in the study.

\subsubsection{Information Form}

This form prepared by the researcher contained questions regarding the mother's age, education and employment status, employment period, health condition, economic condition, family structure, number of children, child's sex, school attendance period, post-partum depression, situation after separation from the child or after separation of the child, whether school adjustment problems were experienced, whether the child had any psychosomatic complaints in the school adjustment process, and how they described their relation with the child.

\subsubsection{Spence Children's Anxiety Scale - Parent Form}

Scale was prepared by Spence in a way that the items in the children's form could be answered by the parents (Spence, 1999). Scale consists of 38 items related with anxiety and two open-ended questions, which were not evaluated with points. The highest score that can be obtained from the scale was calculated as 114 and the cut-off point was recommended as 28 points (for a 3point likert scale). In addition to providing general information on anxiety level, it provides information on panic attack and agoraphobia, separation anxiety, fear of physical injury, social phobia, obsessive compulsive disorder and generalized anxiety diagnosis. Each item is evaluated over a 4point likert type scale between 0 - 3. Study results have shown the reliability coefficient of the whole scale as 0.89 for both normal and clinical sample (Nauta et al., 2004). Moreover, reliability analysis of Spence Children's Anxiety Scale was realized during the study and the Cronbach Alpha value was found as 0.945 .

\subsubsection{Adult Attachment Style Scale (AASS)}

AASS consists of two sections. The first section, 
developed by Hazan and Shaver (1987), consists of three statements that provide for classification of each adult's attachment as secure, anxious/ambivalent and avoidant and that contains definitions regarding relationship with parents during childhood and general behavior characteristics. Second section of the scale, developed by Mikulincer et al. (1990), consists of 15 items, each of which is required to be given a point between 1- 7 by the participant. Each attachment type is represented with 5 items and the item that received the highest point determines the attachment style of the individual filling the scale. While the internal consistency of the study was found to be acceptable for avoidant and anxious/ambivalent attachment (Cronbach $\alpha=$ 0,61 and 0,66 , respectively), it was found to be weak for secure attachment (Cronbach $\alpha=0,42$ ), as a restriction emphasized previously in literature (Garbarino 1998). Reliability analysis of the Adult Attachment Style Scale was realized in the study and the Cronbach Alpha value was found as 0.623 .

\subsection{Data Analysis}

Kolmogorov-Simirnov test was used to ensure normality assumption in data analysis and it was found that normality assumption of data was fulfilled substantially as a result of the analysis. Thus, parametrical statistical methods were preferred. The "t test" was used in binary comparisons. "F test" was applied to groups with more than two. DUNCAN test was used to determine the groups creating the difference, when there was difference based on the ANOVA(F) test result. SPSS package program was used in the statistical analyses.

\section{Findings and Discussions}

It is seen in Table 1, which provides data regarding children's sex and attachment styles of the mothers, that sex only created a difference in the scores of mothers with anxious attachment style. Attention must be drawn to the fact that the scores of mothers with anxious attachment style who have a daughter are higher than those who have a son.

Sex preference is one of the areas with socio-cultural basis. Especially in patriarchal social structures, having a son is considered as an element that affects the place and value of the woman for the spouse, family and the society (Üstünöz et al., 2010). This point of view may be reflected to pregnancy, fertility and more importantly to the attachment with the baby of the woman (Hergüner et al., 2014). In the prenatal period, in which the sex of the baby is determined, having a baby of the preferred sex may lead to positive feelings towards motherhood and have a positive effect on attachment (Kamel et al., 1999; Köse \& Çınar, 2013). Although a clear distinction is not observed between female and male sex when examined in the context of having a child and sex preference, one may speak of relative superiority of the wish of having a son (Gibson, Michella \& Hindin, 2007; Loo et el., 2010; Üstünöz et al., 2010). No differences are observed in attachment level in sex preference especially in the first child. The most significant reason of this may be general health condition of the baby being considered more important (Sezer, 2010; Öztürk, Kavlak \& Sevil, 2012). In a study on maternal neurobiology, it was found that oxytocin-receptor binding (Francis et al., 2002) in the MPOA (medial preoptic area) and expression of alpha receptors on these oxytocinergic neurons (Champagne et al., 2003) were found to be increased in animals who lick their female babies more and in female babies of these. In other words, in addition to the MPOA oxytocin neurons playing an important role in the attachment of the mother to the child, it also plays an important role in transfer of motherhood style from mother to daughter generation to generation (Eşel, 2010).

Table 1. Child's sex and mother's attachment style points

\begin{tabular}{|c|c|c|c|c|c|}
\hline Attachment style & Sex & $\mathrm{n}$ & Mean \pm Std. error & $\mathrm{t}$ & $\mathrm{p}$ \\
\hline \multirow[t]{2}{*}{ Secure Attachment ${ }^{1}$} & Girl & 72 & $20.83 \pm 0.65$ & \multirow{2}{*}{-0.632} & \multirow{2}{*}{0.388} \\
\hline & Boy & 72 & $21.46 \pm 0.73$ & & \\
\hline \multirow[t]{2}{*}{ Avoidant Attachment } & Girl & 72 & $18.92 \pm 0.73$ & \multirow{2}{*}{0.613} & \multirow{2}{*}{0.854} \\
\hline & Boy & 72 & $18.25 \pm 0.79$ & & \\
\hline \multirow[t]{2}{*}{ Avoidant attachment } & Girl & 72 & $18.63 \pm 0.52$ & \multirow{2}{*}{1.562} & \multirow{2}{*}{$0.040^{*}$} \\
\hline & Boy & 72 & $17,35 \pm 0,63$ & & \\
\hline
\end{tabular}

${ }^{1}$ Each attachment style is evaluated within itself.

* Important at 0.05 level 
Table 2. Income level and mother's attachment style points

\begin{tabular}{|l|l|c|c|c|c|}
\hline Attachment style & Family income level & $\mathrm{n}$ & Mean \pm Std. error & $\mathrm{t}$ & $\mathrm{p}$ \\
\hline \multirow{2}{*}{ Secure Attachment ${ }^{1}$} & Good & 101 & $21.50 \pm 0.58$ & \multirow{2}{*}{1.085} & \multirow{2}{*}{0.280} \\
\cline { 2 - 4 } & Average & 43 & $20.33 \pm 0.91$ & & \multirow{2}{*}{$0.046^{*}$} \\
\hline \multirow{2}{*}{ Avoidant Attachment } & Good & 101 & $16.93 \pm 1.02$ & \multirow{2}{*}{2.080} & \\
\cline { 2 - 4 } Anxious attachment & Average & 43 & $19.29 \pm 0.63$ & & \multirow{2}{*}{$0.004^{* *}$} \\
\hline
\end{tabular}

${ }^{1}$ Each attachment style is evaluated within itself.

*Important at 0.05 level

${ }^{* * *}$ Important at 0.01 level

Table 3. Child's and Mother's Reaction to Separation and Mother's Attachment Style Points

\begin{tabular}{|c|c|c|c|c|c|c|c|c|c|c|}
\hline Attachment style & $\begin{array}{l}\text { Reaction to } \\
\text { separation } \\
\text { from mother }\end{array}$ & $\mathrm{n}$ & $\begin{array}{l}\text { Mean } \pm \text { Std. } \\
\quad \text { error }\end{array}$ & $\mathrm{t}$ & $\mathrm{p}$ & $\begin{array}{c}\text { Reaction to } \\
\text { separation from } \\
\text { the child }\end{array}$ & $\mathrm{n}$ & $\begin{array}{l}\text { Mean } \pm \text { Std. } \\
\text { error }\end{array}$ & $\mathrm{t}$ & $\mathrm{p}$ \\
\hline \multirow{2}{*}{$\begin{array}{c}\text { Secure } \\
\text { Attachment }{ }^{1}\end{array}$} & Yes & 62 & $19.89 \pm 0.78$ & \multirow{2}{*}{-2.248} & \multirow{2}{*}{$0.026^{*}$} & Yes & 66 & $20.12 \pm 0.80$ & \multirow{2}{*}{-1.927} & \multirow{2}{*}{$0.056^{*}$} \\
\hline & None & 82 & $22.10 \pm 0.61$ & & & None & 78 & $22.01 \pm 0.59$ & & \\
\hline \multirow{2}{*}{$\begin{array}{c}\text { Avoidant } \\
\text { Attachment }\end{array}$} & Yes & 62 & $19.00 \pm 0.81$ & \multirow{2}{*}{0.666} & \multirow{2}{*}{0.506} & Yes & 66 & $19.53 \pm 0.81$ & \multirow{2}{*}{1.614} & \multirow{2}{*}{0.109} \\
\hline & None & 82 & $18.27 \pm 0.72$ & & & None & 78 & $17.78 \pm 0.72$ & & \\
\hline \multirow{2}{*}{$\begin{array}{c}\text { Anxious } \\
\text { attachment }\end{array}$} & Yes & 62 & $18.71 \pm 0.59$ & \multirow{2}{*}{1.538} & \multirow{2}{*}{0.126} & Yes & 66 & $19.00 \pm 0.58$ & \multirow{2}{*}{2.303} & \multirow{2}{*}{$0.023^{*}$} \\
\hline & None & 82 & $17.44 \pm 0.55$ & & & None & 78 & $17.13 \pm 0.56$ & & \\
\hline
\end{tabular}

${ }^{1}$ Each attachment style is evaluated within itself.

*Important at 0.05 level.

It is seen in the examination of Table 2 that income level results in a difference in the score of the mothers with avoidant and anxious attachment. The scores of anxious and avoidant attachment which are insecure attachment types, increase as the income level decreases. Moreover, it is seen that income level does not create a difference in secure attachment style.

It is considered that the obtained result is related with maternal behavior more than attachment. It is seen that mothers have intense anxiety towards the child in the post-partum periods. Positive environmental conditions will be supportive in terms of fulfillment of maternal behaviors in this process. In the study of Koç et al. (2016), which examined the relationship between maternal role and parenthood behavior, it was found that the mother's income status perception had a positive effect on the maternal role. Moreover, there are certain study results that indicate that the maternal role scores of mothers with a good income level are higher and that there is a significant relationship between the mother's socio-economic status and the observed maternal behaviors (Çalışır, 2003; Özkan \& Polat, 2011). It is considered that the majority (70\%) of mothers who participated in the study perceiving themselves as being at an economically good level and people with a secure attachment styles evaluating their life quality in a better and positive manner have an effect on the obtained result.

It is seen in Table 3, which provides data on reaction of the child to separation from the mother and reaction of the mother to separation from the child and on the attachment styles of mothers, that reaction of the child in the event separation leads to a difference in the secure attachment style. This effect is a negative one, i.e. increase in the secure attachment points of the mother leads to a decrease in the reaction of the child to separation. Notwithstanding that it is statistically not significant, it is striking that the attachment point values are higher for mothers who have children reacting to separation in both insecure attachment styles of anxious and avoidant attachment. Another data in table 3 is related with reaction status of the mothers to separation from their child. It is seen in the table that there is a negative relationship between secure attachment behavior and the reaction shown by the mother to separation from the child. This shows that mothers with secure attachment give lower reaction to separation from the child. However, this effect is positive in anxious attachment. Reaction to separation increases with the increase in anxious attachments. It is worth mentioning that findings regarding the reaction shown towards separation by the mother and the child in table 3 are coherent within itself.

Necessity for separation from the mother of a child, whose all needs are fulfilled by the mother, at an unexpected time will confuse the child's mind, damage the feeling of trust and lead to development of anxiety. Because children have difficulty in understanding and adapting to situations that occur suddenly. For this reason, negative emotions such as anxiety, fear and concern may arise. Furthermore, parents of children with anxiety disorder have 
similar problems related with anxiety also Dick-Niederhause \& Silverman, 2006). Mother’s anxiety and overprotective behaviors related with separation from the child are related with insecure attachment and may trigger the anxiety and insecurity occurring in the child against separation (Hock \& Schirtzinger, 1992; Loitti, 1992; Van Ijzendoorn, 1995; Frite \&Campo, 2002). Due to direct or indirect effects of the attachment between the mother and the child on emotional control, it is believed that this is determinant in development of anxiety in children (Kerns \& Brumariu, 2014). Emotions such as anxiety and fear may also be developed through modeling.

Verduin and Kendall (2013) found separation from mother anxiety in $24 \%$ of the children and school phobia in $53.1 \%$ of the children in their studies. It is reported in another study that there is separation anxiety in $76 \%$ of children with school phobia (Özcan \& Aysev, 2009). This situation will lead to child experiencing serious difficulties in the fields of functionality (Masi et al., 2006). The situation functions exactly in the opposite direction in secure attachment. Children of mothers, exhibiting secure attachment behaviors, will know that they can reach their mothers even if their mothers are not with them, and this supports development of self-coincidence in children (Burger, 2006).

It is stated that the reaction shown against separation is related with certain genetic factors and parental behaviors in the early period (Silove, 1995). Manicavasagar (2008) stated that attachment realized in the early period becomes more permanent as the person grows and may cause an increase in separation anxiety. The desire to be together at all times can reach a level that it can turn into an obsessive attachment style. It is reported that this adult separation anxiety is related especially with anxious attachment. Attachment is effective over all emotional relations of the person (Ainsworth, 1989). It is seen in the studies conducted that the attachment style of the mother affects the maternal behaviors, that mothers who have secure attachment have better relations with their children and that these mothers perceive themselves as better and sufficient parents (Volling, Notaro \& Larsen, 1998).

It is seen in Table 4 that there is no statistical difference between the post-partum depression situation of the mothers participating in the study and their attachment styles. Although, whether the mother experienced post-partum depression or not does not affect the attachment styles, the difference is in negative direction with secure attachment and in positive direction with anxious and avoidant attachment, which are insecure attachment styles. When the secure attachment style increases, the chance of depression is decreased, and the chance of experiencing depression increases with the increase in insecure attachment style.

Although, birth of a new baby is a pleasing and joyful event, this period may be challenging for some mothers. Changes experienced during pregnancy and after birth make the mother biologically and psychologically sensitive and make them open to psychiatric disorders like depression (Evans et al., 2001; Danac1 et al., 2002). Post-partum depression is a very common disorder, and studies conducted in various countries indicate that $10-20 \%$ of mothers suffer from depression in the initial one or two months after birth and 7-15\% suffer from depression in the last months of pregnancy. It appears that increase of these values to levels beyond $20 \%$ will be unavoidable if improvement actions are not taken (Josefsson et al., 2001; Evans et al., 2001; Matthey et al., 2003). In Turkey, the depression was seen in $42 \%$ of mothers after birth that points to a widespread health problem (Buğdaycı et al., 2004). Previous history of depression is also a risk factor for depression (O’Hara, 1996). In addition to these, a relationship is reported in certain studies between insecure attachment style and post-partum depression (Bifulco et al., 2004; Mc Mahon et al., 2005).

Table 4. Post-partum depression situation and mother's attachment style points

\begin{tabular}{|l|l|c|c|c|c|}
\hline Attachment style & Did you experience post-partum depression? & $\mathrm{n}$ & Mean \pm Std. error & $\mathrm{t}$ & $\mathrm{p}$ \\
\hline \multirow{3}{*}{ Secure Attachment ${ }^{1}$} & Yes & No & 42 & $20.60 \pm 0.84$ & \multirow{2}{*}{0.714} \\
\cline { 2 - 5 } & Yes & 102 & $21.37 \pm 0.60$ & 0.476 \\
\cline { 2 - 5 } Avoidant Attachment & No & 42 & $19.45 \pm 1.00$ & \multirow{2}{*}{1.028} & 0.306 \\
\hline \multirow{2}{*}{ Anxious Attachment } & Yes & 102 & $18.23 \pm 0.64$ & & \multirow{2}{*}{1.289} \\
\cline { 2 - 5 } & No & 102 & $18.81 \pm 0.59$ & 0.200 \\
\hline
\end{tabular}

${ }^{1}$ Each attachment style is evaluated within itself. 
According to Bowlby (1980), failure in establishment of secure attachment between the mother and the child will lead to development of depression and anxiety in the subsequent years. This loss will pave the way to creation of negative representations towards the self and the world around him/her and depression for the child (Kohut \& Wolf, 1978). Numerous studies have shown the presence of a relationship between neurotic disorders and attachment styles. Although both insecure attachment types are related with neurotic disorders, it is shown that it has a more significant correlation, especially with the anxious attachment style (Beitel \& Cecero, 2003; Neyer \& Voigt, 2004). Under the light of this information, despite the fact that there is no difference in terms of post-partum depression and attachment styles of mothers, the finding of a negative relationship between post-partum depression and secure attachment, and positive relationship with insecure attachment styles of anxious and avoidant attachment shows that the study results are coherent with literature.

Effects of relationship of mothers with their children on attachment styles are shown in Table 5. It is seen from examination of Table 5 that the scores are highest in mothers who describe their relationship with their children as a "rule-based discipline understanding" in avoidant attachment style. A similar situation is also present in anxious attachment style also, although there is no statistical difference. However, presence of a completely opposite situation in secure attachment style is striking.

Here, the scores are lowest in mothers who describe their relationship with the children as in the form of a "rule-based discipline understanding". Individuals with an avoidant attachment style could not find their mother's near them when needed in early period and have been deprived of this affinity. These individuals do not believe that other people will help them when they face any difficulty and that they can ask for help of others, and they are in an obsessive effort to acquire self-efficacy (Bartholomew \& Shaver, 1998). People with an avoidant attachment style are distant in their relations with their children and are not sensitive towards their needs. In a disciplined attitude, they want their children to cope with the stress conditions encountered without needing the help of anyone. They give the message that the child can only trust himself/herself. Main (1990) associated mothers displaying a consistent unresponsiveness to stress symptoms and needs of the child with avoidant attachment. Against this situation, children respond by developing distance and emotional detachment towards their mother.

Table 5. Mother's definition of the relationship with the child and mother's attachment style points

\begin{tabular}{|c|c|c|c|c|c|}
\hline Attachment style & Definition of relationship with child & $\mathrm{n}$ & Mean \pm Std. Error & $\mathrm{F}$ & $\mathrm{p}$ \\
\hline \multirow{6}{*}{ Secure Attachment ${ }^{1}$} & We are like a friend & 28 & $21.61 \pm 1.42$ & \multirow{6}{*}{1.037} & \multirow{6}{*}{0.398} \\
\hline & We have a warm. cordial relationship & 52 & $21.87 \pm 0.74$ & & \\
\hline & We have challenging. contentious difficult relationship & 23 & $21.09 \pm 1.31$ & & \\
\hline & We display a disciplined attitude with rules & 20 & $18.45 \pm 1.13$ & & \\
\hline & Our relationship continues on the mother-child context & 12 & $21.67 \pm 1.22$ & & \\
\hline & $\begin{array}{l}\text { Requests of our child are a priority. we do everything according to } \\
\text { him/her }\end{array}$ & 9 & $21.00 \pm 1.94$ & & \\
\hline \multirow{6}{*}{$\begin{array}{l}\text { Avoidant } \\
\text { Attachment }\end{array}$} & We are like a friend & 28 & $18.79 \pm 1.11 \mathrm{~b}$ & \multirow{6}{*}{2.461} & \multirow{6}{*}{0.036} \\
\hline & We have a warm. cordial relationship & 52 & $17.54 \pm 0.93 \mathrm{~b}$ & & \\
\hline & We have challenging. contentious difficult relationship & 23 & $17.22 \pm 1.47 \mathrm{~b}$ & & \\
\hline & We display a disciplined attitude with rules & 20 & $22.90 \pm 1.46$ a & & \\
\hline & Our relationship continues on the mother-child context & 12 & $17.42 \pm 1.47 \mathrm{~b}$ & & \\
\hline & $\begin{array}{l}\text { Requests of our child are a priority. we do everything according to } \\
\mathrm{him} / \mathrm{her}\end{array}$ & 9 & $19.44 \pm 1.26 \mathrm{~b}$ & & \\
\hline \multirow{6}{*}{ Anxious attachment } & We are like a friend & 28 & $17.93 \pm 1.07$ & \multirow{6}{*}{1.829} & \multirow{6}{*}{0.111} \\
\hline & We have a warm. cordial relationship & 52 & $17.44 \pm 0.68$ & & \\
\hline & We have challenging. contentious difficult relationship & 23 & $16.74 \pm 1.02$ & & \\
\hline & We display a disciplined attitude with rules & 20 & $20.70 \pm 0.88$ & & \\
\hline & Our relationship continues on the mother-child context & 12 & $17.42 \pm 1.01$ & & \\
\hline & $\begin{array}{l}\text { Requests of our child are a priority. we do everything according to } \\
\mathrm{him} / \mathrm{her}\end{array}$ & 9 & $18.22 \pm 1.64$ & & \\
\hline
\end{tabular}

${ }^{1}$ Each attachment style is evaluated within itself.

*Important at 0.05 level 
The attachment style of mothers affect the perception of the relations with their children and the maternal behaviors. Behavior style of the mother towards her own child is a reflection of the attachment style with her own mother. Thus, the attachment issue is really important. Because it does not affect one but nearly three generations (Main et al., 1985; Benoit \& Parker, 1994; George \& Solomon, 1996). The definitions of relationships of mothers with their children and the attachment styles support the information in literature. When we examine the definition of relationship with their children of mothers with an avoidant attachment style, we see that the highest points are obtained by mothers who describe their relationship with their children as a "rule-based discipline understanding". Individuals with an avoidant attachment style could not find their mother's near them when needed in early period and have been deprived of this affinity. These individuals do not believe that other people will help them when they face any difficulty and that they can ask for help of others, and they are in an obsessive effort to acquire self-efficacy (Bartholomew \& Shaver, 1998). People with an avoidant attachment style are distant in their relations with their children and are not sensitive towards their needs. In a disciplined attitude, they want their children to cope with the stress conditions encountered without needing the help of anyone. They give the message that the child can only trust himself/herself. Main (1990) associated mothers displaying a consistent unresponsiveness to stress symptoms and needs of the child with avoidant attachment. Against this situation, children respond by developing distance and emotional detachment towards their mother. When we examine the data in Table 6 regarding attachment styles of mothers, we see that there is a negative relationship between secure attachment and insecure attachment styles of anxious and avoidant attachment. Accordingly, insecure attachment scores of mothers decrease when the secure attachment scores increase. Moreover, a significant relationship is observed between secure attachment style of mothers and panic attack-agoraphobia $(r=-, 206 ; \mathrm{p}<.05)$, fear of physical injury $(\mathrm{r}=-, 178 ; \mathrm{p}<.05)$ and separation fear $(\mathrm{r}=-, 189 ; \mathrm{p}<.05)$ in the Spence Children's Anxiety Scale. This negative relationship between secure attachment of mothers and anxiety of children is present also in other dimensions (obsessive compulsive disorder, social phobia, generalized anxiety) that are not statistically significant.

Table 6. Spence anxiety scale and mother attachment style correlation

\begin{tabular}{|c|c|c|c|c|}
\hline \multirow{2}{*}{\multicolumn{2}{|c|}{ Spence anxiety scale }} & \multicolumn{3}{|c|}{ Adult Attachment Style } \\
\hline & & \multirow{2}{*}{$\begin{array}{l}\text { Secure } \\
-.206^{*}\end{array}$} & \multirow{2}{*}{$\begin{array}{c}\text { Avoidant } \\
.189 *\end{array}$} & \multirow{2}{*}{$\begin{array}{c}\text { Anxious } \\
.211^{*}\end{array}$} \\
\hline \multirow{3}{*}{ Panic attack-agoraphobia } & Correlation coefficient & & & \\
\hline & Importance degree & .013 & .023 & .011 \\
\hline & $\mathrm{n}$ & 144 & 144 & 144 \\
\hline \multirow{3}{*}{ Obsessive Compulsive Disorder } & Correlation coefficient & -.124 & .084 & $.219 * *$ \\
\hline & Importance degree & 137 & .315 & .008 \\
\hline & $\mathrm{n}$ & 144 & 144 & 144 \\
\hline \multirow{3}{*}{ Fear of physical injury } & Correlation coefficient & $-.178 *$ & .139 & 129 \\
\hline & Importance degree & .033 & .097 & .122 \\
\hline & $\mathrm{n}$ & 144 & 144 & 144 \\
\hline \multirow{3}{*}{ Social phobia } & Correlation coefficient & -.152 & .050 & .091 \\
\hline & Importance degree & .070 & .555 & .277 \\
\hline & $\mathrm{n}$ & 144 & 144 & 144 \\
\hline \multirow{3}{*}{ Separation fear } & Correlation coefficient & $-.189 *$ & $.219 * *$ & $.202 *$ \\
\hline & Importance degree & .023 & .008 & .015 \\
\hline & $\mathrm{n}$ & 144 & 144 & 144 \\
\hline \multirow{3}{*}{ Generalized Anxiety } & Correlation coefficient & -.133 & .100 & $.194 *$ \\
\hline & Importance degree & .111 & .234 & .020 \\
\hline & $\mathrm{n}$ & 144 & 144 & 144 \\
\hline
\end{tabular}

**. Correlation important at 0.01 level (bilateral),

*. Correlation important at 0.05 level (bilateral) 
It is seen that the statistically significant relationships between the avoidant attachment style of mothers and the Children's Anxiety Scale are in the sub-dimensions of panic attack-agoraphobia $(\mathrm{r}=, 189 ; \mathrm{p}<.05)$ and separation fear $(\mathrm{r}=, 219 ; \mathrm{p}<.01)$. This relationship is in the positive direction and the anxiety scores of these dimensions increase when the avoidant attachment score of the mothers increase. Although, not statistically significant, we see this positive relationship in the dimensions of obsessive compulsive disorder, fear of physical injury, social phobia, generalized anxiety and total points. A positive relationship is found between anxious attachment style of mothers and sub dimensions of panic attack-agoraphobia $(\mathrm{r}=.211 ; \mathrm{p}<.05)$, obsessive-compulsive disorder $(r=.219 ; \mathrm{p}<.01)$, separation fear $(\mathrm{r}=.202 ; \mathrm{p}<.05)$ and generalized anxiety $(\mathrm{r}=.194 ; \mathrm{p}<.05)$ of the Children's Anxiety Scale. A statistically significant relationship was not found between anxious attachment style and fear of physical injury and social phobia sub-dimensions of the Children's Anxiety scale.

When attachment is observed within a linear structure in the spectrum, it is seen that the group with over emotional expression (emotion regulation inefficiency) is located at one end of the spectrum and the group with inefficient emotional expression (emotion over-regulation and control) is located at the other. Secure attachment finds a place at the middle section of this spectrum. The point at which the person will be on the spectrum depends on previous experiences, and especially the experiences with the attachment figure. According to the linear model of attachment styles, secure attachment combines medium degree of emotion regulation and expression. Positive self and positive others model is present in persons with secure attachment (Bartholomew \& Horowitz, 1991; Bartholomew \& Shaver, 1998; Park et al., 2004; Yildizhan, 2016). Emotion over-regulation and inefficiency in emotional expression are observed in avoidant attachment and people have positive self and negative others perception (Bartholomew \& Horowitz, 1991; Bartholomew \& Shaver, 1998; Park et al., 2004; Gamble \& Roberts, 2005; Yildizhan, 2016). Inefficient emotional regulation and high emotional expression are observed in anxious attachment and people have negative self and positive others perception (Bartholomew \& Horowitz, 1991; West \& Sheldon-Kellar, 1994; Mickelson, Kessler \& Shaver, 1997; Bartholomew \& Shaver, 1998; Park et al., 2004; Gamble \& Roberts, 2005; Y1ldizhan, 2016). When we examine the results of the studies in literature, we see that they are coherent with the findings of this study.

\section{REFERENCES}

[1] Işık, E.(1996). Neuroses. Kent Printing House, Ankara.

[2] Erdoğan, I., Tamar, M. \& Erdoğan, E.(2002). A comparison of symptomatology in children and adolescents with major depressive disorder. Turkish Journal of Child and Adolescent
Mental Health, 9(3), 144-154.

[3] Kaya, M., Özcan Özel, Ö. \& Kaya, B. (2006). Psychological adaptation on the students who are in two different primary schools which have different socioeconomics conditions in Malatya province. Anatolian Journal of Psychiatry, 7(3), 157-161.

[4] Öztürk, M.(2007). Child psychiatry for parents and educators. İstanbul, Uçurtma Publications ISBN: 9758947225.

[5] Ollendick, T.H. \& Hirshfeld-Becker, D.R.(2002). The developmental psychopathology of social anxiety disorder. Biological Psychiatry, 51(1), 44-58.

[6] Soysal, A., Bodur, Ş., Işeri, E. \& Şenol, S. Attachment process in infancy: A review. Turkish Journal of Clinical Psychiatry, 8, 88-99, 2005.

[7] Tüzün, O., \& Sayar, K.(2006). Attachment theory and psychopathology. Düsünen Adam The Journal of Psychiatry and Neurological Sciences, 19(1), 24-39.

[8] Kesebir, S., Kavzoğlu, S.Ö. \& Üstündağ, M.F. (2011). Attachment and Psychopathology. Current Approaches in Psychiatry, 3(2), 321-342.

[9] Bowlby, J.(1973). Attachment and loss: Separation anxiety and anger (Volume 2). New York: Basic Books. ISBN: o-465-09716-2.

[10] Berstein, G. \& Garfinkel, B.D.(1988). Functioning and psychopathology in families of school phobic children. American Journal of Psychiarty, 145 (1), 70-74.

[11] Elliot, J.G.(1999). Practioner review: School refusal; Issues of conceptualisation, assessment and treatment. Journal of Child Psychology and Psychiatry, 40 (7), 1001-1012.

[12] Kearney, C. A., \& Bates, M.(2005). Addressing school refusal behavior: Suggestions for frontline professionals. Children \& Schools, 27(4), 207-216. Doi:10.1093/cs/27.4.20 7.

[13] Özcan, Ö. \& Aysev, A. (2009). Frequency of Psychiatric Disorders in Children with School Phobia. Journal of Inonu University Medical Faculty, 16 (1), 13-17.

[14] Shaffer, D.R. \& Kipp, K.(2007). Developmental psychology: childhood and adolescence. Belmont, CA: Wodsworth.

[15] Adler, A.(2000). Child Education, (K. Şipal, Trans.). İstanbul, Cem Publisher.

[16] Orta Metin, I \& Sümer, N.(2016). Maternal sensitivity and attachment-based parenting support and intervention programs. Psychological Articles, 19(38), 54-73.

[17] Main, M., Kaplan, N. \& Cassidy, J.(1985). Security in infancy, childhood, and adulthood: A move to the level of representation. Monographs of the Society for Research in Child Development, 50(1-2), 66-104. Doi:10.2307/3333827.

[18] Benoit, D. \& Parker, K. C. H.(1994). Stability and transmission of attachment across three generations. Child Development, 65, 1444-1456.

[19] George, C. \& Soloman, J.(1969). Representational models of relationships: Link between caregiving and attachment. Infant Mental Health Journal, 17, 189-206.

[20] Berk, L. E.(2012). Infants and children, prenatal through 
middle childhood (7th ed.). Allyn \& Bacon. ISBN:0205831915.

[21] Bowlby, J.(1982). Attachment and Bowlby: Attachment (Volume 1). New York: Basic Books.

[22] Bloom, K. C. (1995). The development of attachment behaviors in pregnant adolecents. Nursing Research, 44(5), 284-289.

[23] Stevens, A. \& Price, J. (2000). Evolutionary Psychiatry: A New Beginning, 2nd Ed. London, Routledge.

[24] Bowlby, J. (1980). Attachment and loss: Loss sadness and depression (Volume 3). New York: Random House. ISBN: o-465-04238-4 paper.

[25] Ainsworth M. D. S., Blehar, M. C., Waters, E. \& Wall S. (1978). Pattern of attachment: A psychological study of the strange situation. Hillsdale, $\mathrm{Nj}$ : Erlbaum.

[26] Dönmez, A. (2009). Close Relationships Psychology. Ankara, Nobel Publishing.

[27] Sroufe, L. A. \& Waters E. (1977). Attachment as an organizational construct. Child Development, 48, 1184-1199.

[28] Hazan, C. \& Shaver, P. R. (1994). Attachment as an organizational framework for research on close relationships. Psychological Inquiry, 5(1), 1-22.

[29] Lippe, A., Von Der Eilertsen, D. A., Hartmann, E. \& Kille, K.(2010). The role of maternal attachment in children's attachment and cognitive executive functioning: a preliminary study. Attachment and Human Development, 12(5), 429-444.

[30] Ruppert, F. (2011). Trauma, Attachment and Family Constellations, (F. Zengin, Trans.),1. Ed., İstanbul, Kaknüs Publishing.

[31] Cozolino, L.(2014). The neuroscience of human relationships, (M. Benveniste, Trans.). İstanbul: Psychotherapy Institute Educational Publications.

[32] George, C. \& Soloman, J.(1999). Attachment and caregiving: The caregiving behavioral system. In J. Cassidy \& P.R., Shaver (Eds.). Handbook of Attachment (pp. 649-669). New York, Guilford.

[33] Zimmermann, P. \& Becker-Stoll, F.(2002). Stability of Attachment Representations during Adolescence: The Influence of Ego-Identity. Journal of Adolescence, 25(1), 107-124. Doi: 10.1006/jado.2001.0452.

[34] Van IJzendoorn, M. H.(1995). Adult attachment representations, parental responsiveness and infant attachment: a meta-analysis on the predictive validity of the adult attachment interview. Psychological Bulletin, 117(3), 387-403.

[35] Steele, H., \& Steele, M.(1994). Intergenerational patterns of attachment. In K. Bartholomew \& D. Perlman (Eds.), Advances in personal relationships. Attachment processes in adulthood (Vol. 5, pp. 93-120). London, Jessica Kingsley.

[36] Van IJzendoor, M. H. \& Bakermans-Kranenburg, M. J.(1997). Intergenerational transmission of attachment: A move to the contextual level. In L. Atkinson \& K. J. Zucker (Eds.) Attachment and Psychcology (pp. 135-170). New York: The
Guilford Press.

[37] Güngör, D.(2000). The role of parenting styles in the intergenerational transmission of attachment styles and mental models (Unpublished doctoral dissertation). Ankara University Institute of Social Sciences, Ankara.

[38] Raby, K.L., Steele, R.D., Carlson, E.A. \& Sroufe, L.A.(2015). Continuities and changes in infant attachment patterns across two generations. Attachment \& Human Development, 17(4), 414-28. Doi:10.1080/14616734.2015.1067824.

[39] Peleg, O., Halaby, E., \& Whaby, E. N.(2006). The relationship of maternal separation anxiety and differentiation of self to children's separation anxiety and adjustment to kindergarten: A study in Druze families. Journal of Anxiety Disorders, 20(8), 973-995.

[40] Manicavasagar, V., Silove, D., Rapee, R., Waters, F., \& Momartin, S.(2001). Parent-child concordance for separation anxiety: a clinical study. Journal of Affective Disorders, 65(1), 81-84. Doi: 10.1016/S0165-0327(00)00241 $-X$.

[41] Spence, S. H.(1999). Spence Children's anxiety scale- parent version. Brisbane: University of Queensland.

[42] Nauta, H.M., Scholing, A., Rapee, R.M., Abbott, M., Spence, S. H. \& Waters, A.(2004). A parent-report measure of children's anxiety: psychometric properties and comparison with child-report in a clinic and normal sample. Behaviour Research and Therapy, 42 (7), 813-839.Doi:10.1016/S00057967(03)00200-6.

[43] Hazan, C. \& Shaver, P. R.(1987). Romantic love conceptualized as an attachment process. Journal of Personality and Social Psychology, 52, 511-524. Doi: 10.1037/0022-3514.52.3.511.

[44] Mikulincer, M., Florian, V. \& Tolmacz, R.(1990). Attachment styles and fear of death: A case study of affect regulation. Journal of Personality and Social Psychology, 58(2), 273-280.

[45] Poçi, N., Salaj, A., ..... Hysi, E.(2006). The relationship between attachment style and depression symptoms in university students: A scale adaptation study. Masco Congress, Istanbul.

[46] Garbarino, J. J.(1998). Comparisons of the constructs and psychometric properties of selected measures of adult attachment. Measurement and Evaluation in Counseling and Development, 31(1), 28-45.

[47] Üstünsöz, A., Güvenç, G., Akyüz, A. \& Oflaz, F.(2010). Comparison of maternal-and paternal- fetal attachment in Turkish couples. Midwifery, 26 (2), 1-9.Doi:10.1016/j.midw .2009.12.006

[48] Hergüner, S., Çiçek, E., Annagür, A., Hergüner, A. \& Örs, R.(2014). Association of delivery type with postpartum depression, perceived social support and maternal attachment. Düşünen Adam The Journal of Psychiatry and Neurological Sciences, 27(1), 15-20. Doi: 10.5350/DAJPN2 014270102

[49] Kamel, H.S., Ahmed, H.N., Eissa, M.A. \& Abol-Oyoun al-S. M.(1999). Pyschological and obstetrical responses of mothers following antenatal fetal sex identification. Journal of Obstetrics and Gynaecology Research, 25 (1), 43-50. 
[50] Köse, D., Çınar, N. \& Altınkaynak, S.(2013). Bonding process of the newborn and the parents. Journal of Continuing Medical Education, 22 (6), 230- 236.

[51] Gipson, J. D., Michelle, J. \& Hindin, M.J.(2007). Marriage means having children and forming your family, so what is the need of discussion? Communication and negotiation of childbearing preferences among Bangladeshi couples. Culture, Health \& Sexuality, 9(2), 185-98. Doi: 10.1080/136 91050601065933.

[52] Loo, K.K, Li, Y., Tan, Y., Luo, X., Presson, A. \& Shih, W.(2010). Prenatal anxiety associated with male child preference among expectant mothers at 10-20 weeks of pregnancy in Iangyun country, China. International Journal of Gynecology and Obstetrics, 111, 229-33.

[53] Öztürk, M.(2007). Child psychiatry for parents and educators. İstanbul, Uçurtma Publications ISBN: 9758947225.

[54] Francis, D. D., Young, L. J., Meaney, M. J. \& Insel, T.R.(2002). Naturally occurring differences in maternal care are associated with the expression of oxytocin and vasopressin (V1a) receptors: gender differences. Journal of Neuroendocrinol, 14(5), 349-353.

[55] Champagne, F.A., Weaver, I.C, Diorio, J., Sharma, S. \& Meaney, M.J.(2003). Natural variations in maternal care are associated with estrogen receptor alpha expression and estrogen sensitivity in the medial preoptic area. Endocrinology, 144(11), 4720-4724.

[56] Eşel, E.(2010). Neurobiology of motherhood. Turkish Journal of Psychiatry, 21(1), 68-78.

[57] Koç, Ö., Özkan, H. \& Bekmezci, H.(2016). Evaluating the correlation between maternal role and parenting behavior. Journal of Dr. Behçet Uz Children's Hospital, 6(2), 143-150. Doi: 10.5222/buchd.2016.143

[58] Çalışır, H.(2003). The examination of the factors that affect the maternal role attainment of first-time mothers (Unpublished doctoral dissertation). Ege University Institute of Health Sciences, Izmir.

[59] Özkan, H. \& Polat, S.(2011). Process of motherhood-behavior learning and nursing support. Journal of Bozok University Medical Faculty, 1(3), 5-9.

[60] Dick-Niederhauser, A., \& Silverman, W. K.(2006). Separation anxiety disorder. Practitioner's guide to evidence-based psychotherapy (pp. 627-633), Springer.

[61] Hock, E. \& Schirtzinger, M.B.(1992). Maternal separation anxiety: Its developmental course and relation to maternal mental health. Child Development, 63 (1), 93-102.

[62] Loo, K.K, Li, Y., Tan, Y., Luo, X., Presson, A. \& Shih, W.(2010). Prenatal anxiety associated with male child preference among expectant mothers at 10-20 weeks of pregnancy in Iangyun country, China. International Journal of Gynecology and Obstetrics, 111, 229-33.

[63] Fritz G.K. \& Campo J.V. (2002). Somatoform disorders. In Lewis M (Ed.). Child and adolescent psychiatry: A Comprehensive Textbook (pp.847-858). Lippincot Williams and Wilkins, Philadelphia.

[64] Kerns, K. A., \& Brumariu, L. E.(2014). Is insecure parentchild attachment a risk factor for the development of anxiety in childhood or adolescence? Child Development
Perspectives, 8(1), 12-17.

[65] Verduin, T.L. \& Kendall, P.(2003). Differential occurence of comorbidity within childhood anxiety disorders. Journal of Clinical Child and Adolescent Psychology, 32 (2), 290-295.

[66] Masi, G., Mucci, M. \& Millepiedi, S.(2001). Separation anxiety disorder in children and adolescents. CNS Drugs, 15 (2), 93-104. Doi: 10.2165/00023210-200115020-00002

[67] Burger, J. M.(2006). Personality (Trans. İnan, Deniz). Kaknüs Publishing.

[68] Silove, D., Harris, M., Morgan, A., Boyce, P., Manicavasagar, V., Hadzi-Pavlovic, D., \& Wilhelm, K.(1995). Is early separation anxiety a specific precursor of panic disorderagoraphobia? A community study. Psychological Medicine, 25(02), 405-411.

[69] Manicavasagar, V., Silove, D., Rapee, R., Waters, F., \& Momartin, S.(2001). Parent-child concordance for separation anxiety: a clinical study. Journal of Affective Disorders, 65(1), 81-84. Doi: 10.1016/S0165-0327(00)00241 $-\mathrm{X}$

[70] Ainsworth M. D. S., Blehar, M. C., Waters, E. \& Wall S.(1978). Pattern of attachment: A psychological study of the strange situation. Hillsdale, $\mathrm{Nj}$ : Erlbaum.

[71] Volling, B.L., Notaro, P.C. \& Larsen, J.L.(1998). Adult attachment styles: Relations with emotional well-being, marriage, and parenting. Family Relations, 47 (4), 355-367. Doi: $10.2307 / 585266$

[72] Evans, J., Heron, J., Francomb, H., Oke, S., \& Golding, J.(2001). Cohort study of depressed mood during pregnancy and after childbirth. British Medical Journal, 323(7307), 257- 260 .

[73] Danacı, A. E., Dinç, G., Deveci, A., Şen Seyfe, F. \& İçelli, I.(2002). Postnatal depression in Turkey: epidemiological and cultural aspects. Social Psychiatry and Psychiatric Epidemiolgy, 37 (3), 125-129.

[74] Matthey, S., Barnett, B., Howie, P. \& Kavanaqh, D.J.(2003). Diagnosing postpartum depression in mothers and fathers: whatever happened to anxiety? Journal of Affective Disorders, 74(2), 139-147.

[75] Buğdaycı, R., Şaşmaz, C.T., Tezcan, H., Kurt, A.O. \& Oner, S.(2004). A cross-sectional prevalence study of depression at various times after delivery in Mersin province in Turkey. Journal of Women's Health, 13 (1), 63-68.

[76] O’Hara, M.W.(1996). The nature of postpartum depressive disorders. In L. Murray \& P. J. Cooper (Eds.), Postpartum Depression and Child Development. New York, Guilford Press.

[77] Bifulco, A., Figueiredo, B., Guedeney, N., Gorman, L.L., Hayes, S., Muzik, M., Glatiqny-Dallay, E., Valoriani, V., Kammerer, M.H. \& Henshaw, C.A.(2004). Maternal attachment style and depression associated with childbirth: Preliminary results from a European and US crosscultural study. The British Journal of Psychiatry Supplement, 46, 31-37.

[78] McMahon, C., Barnett, B., Kowalenko, N. \& Tennant, C.(2005). Psychological factors associated with persistent postnatal depression: past and current relationships, defence styles and the mediating role of insecure attachment style. 
Journal of Affective Disorders, 84 (1), 15-24.

[79] Kohut, H., \& Wolf, E. S.(1978). The disorders of the self and their treatment: An outline. International Journal of Psychoanalysis, 59, 413-426.

[80] Beitel, M., \& Cecero, J. J.(2003). Predicting psychological mindedness from personality style and attachment security. Journal of Clinical Psychology, 59(1), 163-172.

[81] Neyer, J.F. \& Voigt, D.(2004). Personality and social network effects on romantic relationships: A dyadic approach. European Journal of Personality, 18(4), 279-299. Doi: 10.1002/per.519.

[82] Main, M., Kaplan, N. \& Cassidy, J.(1985). Security in infancy, childhood, and adulthood: A move to the level of representation. Monographs of the Society for Research in Child Development, 50(1-2), 66-104. Doi: 10.2307/3333827

[83] Bartholomew, K. \& Shaver, P. R.(1998). Methods of assessing adult attachment do they converge? In J. A. Simpson. \& W. S. Rholes (Eds.), Attachment theory and close relationships (pp. 25-46). New York: The Guilford Press.

[84] Main, M., Kaplan, N. \& Cassidy, J.(1985). Security in infancy, childhood, and adulthood: A move to the level of representation. Monographs of the Society for Research in Child Development, 50(1-2), 66-104. Doi: 10.2307/3333827

[85] Main, M., Kaplan, N. \& Cassidy, J.(1985). Security in infancy, childhood, and adulthood: A move to the level of representation. Monographs of the Society for Research in Child Development, 50(1-2), 66-104. Doi:10.2307/3333827

[86] Bartholomew, K. \& Horowitz, L. M.(1991). Attachment styles among young adults: A test of a four-category model. Journal of Personality and Social Psychology, 61, 226-244.

[87] Park, L.E., Crocker, J. \& Mickelson, K.D.(2004). Attachment styles and contingencies of self-worth. Personality and Social Psychology Bulletin, 30(10), 1243-1254.

[88] Yildizhan, E.(2016). Attachment theory and overview of attachment disorders. Anatolian Clinic, 22 (1), 66-72. Doi: 10.21673/anadoloklin.237462

[89] Gamble, S. A., \& Roberts, J. E.(2005). Adolescents' perceptions of primary caregivers and cognitive style: The roles of attachment security and gender. Cognitive Therapy and Research, 29, 123-141.

[90] West, M.L. \& Sheldon-Keller, A. E.(1994). Patterns of Relating: An Adult Attachment Perspective. New York, Guilford Press.

[91] Mickelson, K. D., Kessler, R. C., \& Shaver, P. R.(1997). Adult attachment in a nationally representative sample. Journal of Personality and Social Psychology, 73(5), 1092-1106. Doi: 10.1037/0022-3514.73.5.1092 